\title{
Valuasi ekonomi wisata alam Taman Nasional Kerinci Seblat (TNKS) di Kabupaten Kerinci, Provinsi Jambi : menggunakan Contingent Valuation Method
}

\author{
Asri Evanita Simangunsong; *M Ridwansyah; Yohanes Vyn Amzar \\ Prodi Ekonomi Pembangunan Fak.Ekonomi dan Bisnis Universitas Jambi \\ Email Koresponden: mridwansyahjbi@gmail.com
}

\begin{abstract}
This research was conducted on the attraction of Kerinci Seblat National Park located in Pelompek Village, Kerinci Regency, Jambi Province. This study aims to find out how visitors assess the Kerinci Seblat National Park and where visitors come. This study also aims to determine the economic value of the Kerinci Seblat National Park using the Contingent Valuation method in Kerinci Regency, Jambi Province. The total population used as a sample in this study was 99 people. The method used in this research is accidental sampling method. The analytical method used in this study is a descriptive method using the Contingency Valuation Method. From the results of this study was concluded that visitors to the general assessment of the Kerinci Seblat National Park, Kerinci Regency, Jambi Province were quite good. It can be seen from the highest visitor response of $62.92 \%$. Originally tourists come from within the country and from abroad. The economic value of the Kerinci Seblat National Park using the Contingency Valuation Method approach in the Kerinci Regency, based on an analysis of tourist responses to the existence of natural tourism in the Kerinci Seblat National Park. The WTP willingness value is IDR 50.306.
\end{abstract}

Keywords: Gender, Age, Education, Tourist Origin, and Income.

\begin{abstract}
Abstrak
Penelitian ini bertujuan untuk mengetahui bagaimana penilaian pengunjung tentang Taman Nasional Kerinci Seblat dan dimana pengunjung datang dan pergi. Penelitian ini juga bertujuan untuk mengetahui nilai ekonomi Taman Nasional Kerinci Seblat dengan metode Contingent Valuation di Kabupaten Kerinci Propinsi Jambi. Populasi total yang digunakan sebagai sampel dalam penelitian ini adalah 99 orang. Metode yang digunakan dalam penelitian ini adalah metode aksidental sampling. Metode analisis yang digunakan dalam penelitian ini adalah metode deskriptif dengan menggunakan Metode Valuasi Kontingensi. Dari hasil penelitian ini disimpulkan bahwa pengunjung penilaian umum terhadap Taman Nasional Kerinci Seblat Kabupaten Kerinci Propinsi Jambi cukup bagus. Hal ini dapat dilihat dari jawaban pengunjung tertinggi sebesar $62,92 \%$. Asal wisatawan berasal dari dalam Negeri maupun dari Luar Negeri. Nilai ekonomi Taman Nasional Kerinci Seblat dengan pendekatan Metode Valuasi Kontingensi di Kabupaten Kerinci, berdasarkan analisis respon wisatawan terhadap keberadaan pariwisata alam Taman Nasional Kerinci Seblat. Nilai kesediaan WTP adalah sebesar Rp. 50.306 .
\end{abstract}


Kata kunci : Jenis Kelamin, Usia, Pendidikan, Asal Wisatawan, dan Pendapatan. PENDAHULUAN

Salah satu taman nasional yang potensial bagi kegiatan wisata alam di provinsi Jambi yaitu Taman Nasional Kerinci Seblat (TNKS). Berdasarkan SK Menhut No.420/Menhut-II/2004 tanggal 19 Oktober 2004, luas TNKS yang membantang di Bengkulu, Jambi, Sumatera Selatan, dan Sumatera Barat ini sekitar 1.389.510 hektare. Peran vital yang tidak disangsikan adalah sebagai daerah tangkapan air untuk 23 sungai utama di empat provinsi tersebut.

TNKS merupakan sebuah kawasan pelestarian alam yang mengandung potensi wisata alam, antara lain berupa keanekaragaman hayati, pemandangan alam, dan karakteristik sosial budaya masyarakat setempat yang khas. Pengembangan pariwisata alam di TNKS Kabupaten Kerinci Propinsi Jambi tersebut akan mendukung kelestarian Kawasan karena pengembangannya didasarkan atas prinsip-prinsip ekologi.

Tabel 1. Data kunjungan wisatawan Kabupaten Kerinci

\begin{tabular}{|c|c|c|c|c|c|}
\hline WISMAN & Tahun & $\begin{array}{c}\text { Jumlah } \\
\text { Orang }\end{array}$ & WISNUS & Tahun & $\begin{array}{c}\text { Jumlah } \\
\text { Orang }\end{array}$ \\
\hline & 2000 & 596 & & 2000 & 88807 \\
\hline & 2001 & 897 & & 2001 & 96155 \\
\hline & 2002 & 966 & & 2002 & 104629 \\
\hline & 2003 & 901 & & 2003 & 109435 \\
\hline & 2004 & 936 & & 2004 & 116040 \\
\hline & 2005 & 939 & & 2005 & 116707 \\
\hline & 2006 & 940 & & 2006 & 110064 \\
\hline & 2007 & 876 & & 2007 & 99339 \\
\hline & 2008 & 867 & & 2008 & 99340 \\
\hline & 2009 & 727 & & 2009 & 73679 \\
\hline & 2010 & 81 & & 2010 & 84012 \\
\hline & 2011 & 52 & & 2011 & 14375 \\
\hline & 2012 & 49 & & 2012 & 14370 \\
\hline & 2013 & 1235 & & 2013 & 38985 \\
\hline & 2014 & 1865 & & 2014 & 70550 \\
\hline & 2015 & 1239 & & 2015 & 112496 \\
\hline & 2016 & 7465 & & 2016 & 106542 \\
\hline & 2017 & 2932 & & 2017 & 218315 \\
\hline & 2018 & 6598 & & 2018 & 349326 \\
\hline
\end{tabular}

Dilihat dari data kunjungan wisatawan TNKS dari tahun 2000 sampai tahun 2018 secara keseluruhan mengalami fluktuasi, baik dari wisatawan nusantara maupun wisatawan mancanegara. Kenaikan secara pesat hanya terjadi pada tahun 2016 yakni mencapai 7465 orang. Namun pada tahun 2017 terjadi penurunan sekitar $61 \%$ kemudian pada tahun 2018 terjadi kenaikan kembali sebesar 125\%. Berbeda dengan wisatawan nusantara yang mengalami naik turunnya jumlah kunjungan dari tahun ke tahun, pada tahun 2000 jumlah wisnus lebih sedikit dibandingkan dengan tahun yang lainnya yaitu hanya sebesar 88807 orang dan pada tahun 2018 mengalami kenaikan yang sangat pesat yakni sebesar 349326 orang.

Manfaat ekonomi pengembangan wisata alam TNKS juga memberikan manfaat sosial. Melalui pariwisata alam, nilai-nilai seni budaya asli di Kabupaten Kerinci akan 
lestari keberadaannya karena adanya peningkatan kesadaran dari masyarakat setempat maupun wisatawan terhadap konservasi alam dan asset-aset budaya. Dampak positif dari aspek sosial dapat ditingkatkan jika pemanfaatan tradisional diakomodir oleh stakeholder pariswisata alam TNKS. Masyarakat setempat diberikan kesempatan meneruskan praktek tradisional, sehingga mereka menjadi mitra dalam pelestarian alam TNKS.

Berdasarkan hal-hal tersebut, maka dilakukan penelitian untuk mengkaji Valuasi Ekonomi Wisata Alam Taman Nasional Kerinci Seblat (TNKS) di Kabupaten Kerinci Provinsi Jambi.

\section{METODE}

Metode analisis data yang digunakan untuk menjawab tujuan ketiga yaitu besarnya nilai ekonomi wisata alam dikawasan TNKS maka digunakan analisis kuantitatif dengan menggunakan WTP (Willingness To Pay) sehingga dapat mengetahui besarnya nilai ekonomi wisata alam dikawasan TNKS. Untuk mengetahui tujuan keempat faktor yang mempengaruhi nilai ekonomi wisata alam dikawasan TNKS digunakan analisis kuantitatif menggunakan WTP regresi linear berganda.

Pendekatan nilai kontingensi akan diperoleh persamaan regresi untuk willingness to pay (WTP) (Muryani, 2013), yaitu :

$\mathbf{Y}_{\mathrm{i}}=\boldsymbol{\beta}_{0}+\boldsymbol{\beta}_{1} \mathbf{X}_{1} \mathrm{DS}+\boldsymbol{\beta}_{2} \mathbf{X}_{2}+\beta_{3} \mathbf{X}_{3} \mathrm{DP}+\boldsymbol{\beta}_{4} \mathbf{X}_{4} \mathrm{DW}+\boldsymbol{\beta}_{5} \mathbf{X}_{5}+\mathrm{e}_{\mathrm{i}}$

Keterangan :

$\mathrm{Y}_{\mathrm{i}}$

$\beta_{0} \quad=$ Konstanta

$\beta_{1,2,3,4,5} \quad=$ Koefisien regresi

$\mathrm{X}_{1} \quad=$ Jenis kelamin

$\mathrm{X}_{2} \quad=$ Usia

$\mathrm{X}_{3} \quad=$ Tingkat Pendidikan

$\mathrm{X}_{4} \quad=$ Asal Wisatawan

$\mathrm{X}_{5} \quad=$ Pendapatan keluarga

$\mathrm{e}_{\mathrm{i}} \quad=$ Error/ variabel pengganggu

Uji statistik regresi berganda digunakan untuk menguji signifikan atau tidaknya hubungan lebih dari dua variabel melalui koefisien regresinya. Untuk memudahkan dalam analisis data, penelitian ini menggunakan bantuan Eviews.

\section{HASIL PENELITIAN DAN PEMBAHASAN}

\section{Potensi sumber daya wisata alam TNKS di Kabupaten Kerinci}

Potensi sumber daya obyek wisata alam lainnya adalah Danau Kerinci, Danau Gunung Tujuh, Danau Lingkat, Air Terjun, Gunung Kerinci, Air Panas, Aroma Peco, Goa, Panorama Alam, Batu Gong Pondok, Batu Bersurat, Mesjid Agung Pondok Tinggi, Mesjid Keramat Pulau Tengah, Periuk tembikar Rawang dan Tulisan Rencong pada kulit kayu dan tanduk. Danau Gunung Tujuh merupakan danau yang berada diatas pegunungan bukit barisan dan tercatat sebagai danau tertinggi di Asia Tenggara, sementara Gunung Kerinci tercatat sebagai gunung berapi aktif tertinggi di Indonesia.

Tidak jauh berbeda dengan kekayaan flora, pada kawasan TNKS juga terdapat berbagai jenis fauna yaitu mencapai 37 jenis mamalia, 139 jenis burung, 10 jenis reptelia dan 6 jenis primata. Berbagai jenis satwa langka lainnya yang ditemukan adalah badak sumatera (dicerorphinis sumatrensis), harimau sumatera (phantera tigiris), macan 
dahan (neopelis nebbulosa, kambing hutan (capricornis sumatrensis, dengan jenis primata seperti siamang (sympalangus syndactilus), ungko (hylobetes agilis), simpai (presbytis melaluphos), wau-wau hitam (Hylobates lar), beruk (maraca nemestrina, kera (mancaca dascicu-laris) dan fauna lainnya.

\section{Perkembangan wisata alam meliputi jumlah kunjungan, asal wisatawan wisata alam di TNKS}

perkembangan jumlah kunjungan Wisatawan Mancanegara dan Wisatawan Nusantara di TNKS dari tahun ke tahun terus mengalami fluktuasi. Gejala naik turunnya kunjungan Wisatawan Mancanegara dan Wisatawan Nusantara disebabkan oleh berbagai faktor yang memiliki keterkaitan terhadap jumlah kunjungan Wisatawan Mancanegara dan Wisatawan Nusantara ke TNKS Kerinci.

Tabel 2. Perkembangan jumlah kunjungan wisata alam wisatawan nusantara dan wisatawan mancanegara di TNKS Tahun 2000-2018

\begin{tabular}{|c|c|c|c|c|c|c|c|}
\hline WISMAN & Tahun & $\begin{array}{c}\text { Jumlah } \\
\text { Orang }\end{array}$ & $\begin{array}{c}\text { Perkemban } \\
\text { gan } \\
(\%)\end{array}$ & WISNUS & Tahun & $\begin{array}{c}\text { Jumlah } \\
\text { Orang }\end{array}$ & $\begin{array}{c}\text { Perkemb } \\
\text { angan } \\
(\%)\end{array}$ \\
\hline & 2000 & 596 & & & 2000 & 88807 & \\
\hline & 2001 & 897 & 50,50 & & 2001 & 96155 & 8,27 \\
\hline & 2002 & 966 & 7,69 & & 2002 & 104629 & 8,81 \\
\hline & 2003 & 901 & $-6,72$ & & 2003 & 109435 & 4,59 \\
\hline & 2004 & 936 & 3,88 & & 2004 & 116040 & 6,03 \\
\hline & 2005 & 939 & 0,32 & & 2005 & 116707 & 0,57 \\
\hline & 2006 & 940 & 0,10 & & 2006 & 110064 & $-5,69$ \\
\hline & 2007 & 876 & $-6,80$ & & 2007 & 99339 & $-9,74$ \\
\hline & 2008 & 867 & $-1,02$ & & 2008 & 99340 & 0,01 \\
\hline & 2009 & 727 & $-16,14$ & & 2009 & 73679 & $-25,83$ \\
\hline & 2010 & 81 & $-88,85$ & & 2010 & 84012 & 14,02 \\
\hline & 2011 & 52 & $-35,80$ & & 2011 & 14375 & $-82,88$ \\
\hline & 2012 & 49 & $-5,76$ & & 2012 & 14370 & $-0,03$ \\
\hline & 2013 & 1235 & 2,42 & & 2013 & 38985 & 171,29 \\
\hline & 2014 & 1865 & 51,01 & & 2014 & 70550 & 80,96 \\
\hline & 2015 & 1239 & $-33,56$ & & 2015 & 112496 & 59,45 \\
\hline & 2016 & 7465 & 502,50 & & 2016 & 106542 & $-5,29$ \\
\hline & 2017 & 2932 & $-60,70$ & & 2017 & 218315 & 104,90 \\
\hline & 2018 & 6598 & 125,03 & & 2018 & 349326 & 60,01 \\
\hline
\end{tabular}

Sumber : Dinas Pemuda Olahraga dan Kebudayaan Kab. Kerinci 2018.

Tabel kunjungan wisatawan diatas dapat dilihat bahwa jumlah kunjungan Wisatawan Mancanegara maupun Wisatawan Nusatara yang terus mengalami fluktuasi dari tahun 2000 sampai tahun 2018. Data menunjukkan bahwa jumlah kunjungan wisatawan ke Kabupaten Kerinci belum meningkat secara signifikan.

\section{Nilai Ekonomi Wisata Alam di kawasan TNKS di Kabupaten Kerinci}

Pengukuran dari nilai tambah pada sesuatu di ilmu ekonomi adalah berdasarkan pandangan dari individu, sehingga indikatornya adalah keinginan membayar (WTP) untuk mengkonsumsi atau tidak mengkonsumsi sesuatu. Oleh karenanya, nilai tambah yang didapatkan suatu individu pasti akan sebanding dengan kesediaan membayar seseorang untuk menikmati sesuatu tersebut. Konsep 
nilai ekonomi bukan hanya menyangkut nilai pemanfaatan langsung dan tidak langsung semata.

Tabel 3. Nilai ekonomi wisata alam di kawasan TNKS di Kabupaten Kerinci

\begin{tabular}{|c|c|c|c|c|c|c|}
\hline $\begin{array}{c}\text { Nilai } \\
\text { kesediaan } \\
\text { membayar } \\
\text { /WTP } \\
\text { (Rp/orang) }\end{array}$ & $\begin{array}{c}\text { Rata- } \\
\text { rata } \\
\text { interval } \\
\text { nilai } \\
\text { kesediaa } \\
\text { n } \\
\text { membay } \\
\text { ar/WTP } \\
\text { (Rp) }\end{array}$ & $\begin{array}{c}\text { Prosentase } \\
\text { Pengunjun } \\
\mathrm{g}(\%)\end{array}$ & $\begin{array}{c}\text { Prosenta } \\
\text { se } \\
\text { Kumulati } \\
\text { f }(\%)\end{array}$ & $\begin{array}{c}\text { Proporsi } \\
\text { Pilihan } \\
\text { jumlah } \\
\text { pengunjun } \\
\text { g } \\
\text { (orang/tah } \\
\text { un) }\end{array}$ & $\begin{array}{c}\text { Jumlah } \\
\text { kesediaan } \\
\text { membayar } \\
/ \text { WTP } \\
\text { (Rp/tahun) }\end{array}$ & $\begin{array}{c}\text { Jumlah } \\
\text { kumulatif } \\
\text { nilai } \\
\text { kesediaan } \\
\text { membayar/ } \\
\text { WTP (Rp) }\end{array}$ \\
\hline $\begin{array}{c}0-50,000 \\
50,000-\end{array}$ & 50,000 & 19 & 100 & 1,881 & 5000000 & 5000000 \\
\hline $\begin{array}{c}100,000 \\
100,000-\end{array}$ & 75,000 & 21 & 79 & 2,079 & 6075000 & 11075000 \\
\hline $\begin{array}{c}150,000 \\
150,000-\end{array}$ & 125,000 & 13 & 66 & 1,287 & 8500000 & 19575000 \\
\hline $\begin{array}{c}200,000 \\
200,000-\end{array}$ & 175,000 & 6 & 60 & 594 & 10850000 & 30425000 \\
\hline $\begin{array}{c}250,000 \\
250,000-\end{array}$ & 225,000 & 7 & 53 & 693 & 12375000 & 42800000 \\
\hline $\begin{array}{c}300,000 \\
300,000-\end{array}$ & 275,000 & 12 & 41 & 1,188 & 11825000 & 54625000 \\
\hline $\begin{array}{c}350,000 \\
350,000-\end{array}$ & 325,000 & 8 & 33 & 792 & 11375000 & 66000000 \\
\hline $\begin{array}{l}400,000 \\
400,000-\end{array}$ & 375,000 & 9 & 24 & 891 & 9750000 & 75750000 \\
\hline $\begin{array}{l}450,000 \\
450,000-\end{array}$ & 425,000 & 2 & 22 & 198 & 10200000 & 85950000 \\
\hline 500,000 & 475,000 & \multicolumn{2}{|c|}{ TOTAL } & 99 & 10925000 & $\begin{array}{c}96875000 \\
\mathbf{4 8 8 0 7 5 0 0 0}\end{array}$ \\
\hline
\end{tabular}

Sumber: Data diolah, 2019

Total kumulatif nilai kesediaan membayar/WTP pengunjung untuk tetap dapat menikmati jasa pariwisata alam dimaksud sebesar Rp.488.075.000,- dengan rata-rata nilai kesediaan membayar/WTP sebesar Rp. 252.500,- per orang.

Faktor-faktor yang mempengaruhi nilai ekonomi wisata alam dikawasan TNKS di Kabupaten Kerinci

Jenis kelamin

Jenis kelamin disini untuk melihat seberapa banyak wisatawan yang berjenis kelamin laki-laki dan perempuan. Distribusi frekuensi responden berdasarkan jenis kelamin dapat dilihat pada tabel dibawah ini :

Tabel 4. Distribusi frekuensi responden berdasarkan jenis kelamin wisatawan di TNKS Kabupaten Kerinci Tahun 2019

\begin{tabular}{ccc}
\hline Jenis Kelamin & Frekuensi & Persentase \\
\hline Laki - Laki & 61 & 61,61 \\
Perempuan & 38 & 38,38 \\
\hline Total & $\mathbf{9 9}$ & $\mathbf{1 0 0 , 0 0}$ \\
\hline
\end{tabular}


Sumber : Data diolah, 2019

Berdasarkan tabel 4 diketahui bahwa responden yang berjenis kelamin laki-laki sebanyak 61 responden atau $61,61 \%$, sedangkan yang berjenis kelamin perempuan sebanyak 38 responden atau 38,38\%. Hal ini berarti bahwa mayoritas responden penelitian adalah laki-laki.

\section{Usia}

Kelompok umur menggambarkan komposisi penduduk dengan jumlah penduduk produktif (15-16 tahun) dan jumlah yang tidak produktif dibawah 15 tahun dan 65 tahun keatas. Umur yang masih muda akan lebih berpeluang bersedia membayar dibandingkan dengan usia yang lebih tua. Distribusi frekuensi responden berdasarkan umur dapat dilihat pada tabel dibawah ini :

Tabel 5. Distribusi frekuensi responden berdasarkan kelompok umur wisatawan di TNKS Kabupaten Kerinci Tahun 2019

\begin{tabular}{ccc}
\hline Kelompok Umur & Frekuensi & Persentase \\
\hline$\leq 24$ & 28 & 28,28 \\
$25-29$ & 30 & 30,30 \\
$30-34$ & 18 & 18,18 \\
$35-39$ & 11 & 11,11 \\
$\geq 40$ & 12 & 12,12 \\
Total & 99 & 100,00 \\
\hline Rata-Rata (Tahun) & $\mathbf{2 9}$
\end{tabular}

Sumber : Data diolah, 2019

Berdasarkan Tabel 5 menunjukkan bahwa distribusi berdasarkan kelompok umur wisatawan di TNKS Kabupaten Kerinci dengan jumlah responden 99, menunjukkan kelompok umur wisatawan tertinggi yaitu antara $\leq 24-29$ tahun sebanyak 58 orang atau 58,6 dan jumlah terendah yaitu 35-39 tahun sebanyak 11 atau 11,11\%. Rata-rata umur wisatawan di TNKS Kabupaten Kerinci yaitu berumur 29 tahun. Pola pikir dan kedewasaan dari tiap individu dapat mempengaruhi kemauan membayar.

\section{Pendidikan}

Tingkat pendidikan seseorang menunjukkan pengetahuan yang dimiliki oleh responden. Semakin tinggi tingkat Pendidikan seseorang maka pemikiran wawasan serta pandangannya akan semakin luas sehingga dapat berfikir lebih cepat dan tepat.. Distribusi frekuensi responden berdasarkan pendidikan dapat dilihat pada tabel dibawah ini:

Tabel 6. Distribusi Frekuensi Responden Berdasarkan Tingkat Pendidikan wisatawan di TNKS Kabupaten Kerinci Tahun 2019

\begin{tabular}{ccc}
\hline Tingkat Pendidikan & Frekuensi & Persentase \\
\hline <SMA/Sederajat & 35 & 35,35 \\
Perguruan Tinggi & 64 & 64,64 \\
\hline Total & $\mathbf{9 9}$ & $\mathbf{1 0 0 , 0 0}$
\end{tabular}

Sumber : Data diolah, 2019 
Berdasarkan tabel 6 di ketahui bahwa para wisatawan TNKS merupakan orangorang yang memiliki pendidikan. Data tersebut menginformasikan bahwa jumlah wisatawan lulusan <SMA/Sederajat kebawah yang paling sedikit yaitu 35 responden atau 35,35\%, dan yang paling banyak lulusan Perguruan Tinggi yaitu 64 responden atau $64,64 \%$. Pendidikan reponden rata-rata adalah pendidikan terdidik, biasanya orang yang memiliki pendidikan tinggi memiliki pemahaman dan penilaian akan pentingnya ligkungan yang baik.

\section{Asal wisatawan}

Asal wisatawan merupakan bagian yang tak terpisahkan dari dunia pariwisata. Wisatawan sangat beragam, tua-muda, miskin-kaya, manca negara- nusantara, semuanya mempunyai keinginan dan harapan yang berbeda.

Tabel 7. Distribusi Frekuensi Responden Berdasarkan Asal Wisawatan pada Tahun 2019

\begin{tabular}{ccc}
\hline Asal Wisatawan & Frekuensi & Persentase \\
\hline Wisman & 31 & 31,31 \\
Wisnus & 68 & 68,68 \\
\hline Total & $\mathbf{9 9}$ & $\mathbf{1 0 0 , 0 0}$
\end{tabular}

Sumber : Data diolah, 2019

Berdasarkan tabel 7 menunjukan bahwa Wisatawan Nusantara lebih banyak yaitu sebesar 68 responden atau 68,68\% dan Wisatawan Mancanegara lebih sedikit yaitu responden atau $31,31 \%$.

\section{Pendapatan keluarga/Rumah tangga}

Pendapatan merupakan fundamental dalam mengambil keputusan wisatawan untuk kesediaan membayar/WTP. Distribusi frekuensi responden berdasarkan jumlah penumpang dapat dilihat pada tabel dibawah ini :

Tabel 8. Distribusi Frekuensi Responden Berdasarkan Pendapatan

Keluarga/Rumah Tangga pada Tahun 2019

\begin{tabular}{ccc}
\hline Pendapatan Keluarga & Frekuensi & Persentase \\
\hline Rp.1.000.000- Rp. 5.000.000 & 53 & 53,53 \\
Rp. 5.000.000- Rp. 10.000 .000 & 15 & 15,15 \\
Rp.10.000.000- Rp.15.000.000 & 12 & 12,12 \\
>Rp.15.000.000 & 19 & 19,19 \\
\hline Total & $\mathbf{9 9}$ & $\mathbf{1 0 0 , 0 0}$
\end{tabular}

Sumber : Data diolah, 2019

Berdasarkan tabel 8 menunjukkan distribusi responden berdasarkan pendapatan dengan jumlah 99 responden, pendapatan tertinggi yaitu antara 1.000.000-5.000.000 sebanyak 53 atau 53,53\% dan pendapatan terendah yaitu antara 10.000.000-15.000.000 sebanyak 12 atau $12,12 \%$.

\section{Lama kunjungan wisatawan TNKS}

Tabel 9. Distribusi Frekuensi Responden Berdasarkan Lama Kunjungan Wisatawan TNKS pada Tahun 2019 


\begin{tabular}{ccc}
\hline Lama Kunjungan & Frekuensi & Persentase \\
\hline $2-5$ jam & 17 & $17,17 \%$ \\
$5-10$ jam & 18 & $18,18 \%$ \\
$10-15$ jam & 32 & $32,32 \%$ \\
$>15$ jam & 32 & $32,32 \%$ \\
\hline Total & $\mathbf{9 9}$ & $\mathbf{1 0 0 , 0 0}$
\end{tabular}

Sumber : Data diolah, 2019

Berdasarkan tabel 9 dapat dilihat bahwa lama kunjungan yang paling lama yaitu 10->15 jam sebanyak 64 responden atau $64,7 \%$ dan yang paling sebentar $2-5$ jam sebanyak 17 responden atau $17,17 \%$.

Kepuasan kunjungan wisatawan TNKS

Tabel 10. Distribusi Frekuensi Responden Berdasarkan Kepuasaan Kunjungan Wisatawan TNKS pada Tahun 2019

\begin{tabular}{ccc}
\hline Kepuasan Kunjungan & Frekuensi & Persentase \\
\hline Puas & 85 & 85,85 \\
Tidak Puas & 14 & 14,14 \\
\hline Total & $\mathbf{9 9}$ & $\mathbf{1 0 0 , 0 0}$
\end{tabular}

Sumber : Data diolah, 2019

Dari tabel 10 diketahui bahwa kepuasan kunjungan wisatawan yang puas lebih banyak sebesar 85 responden atau $85,85 \%$ dan yang tidak puas sebanyak 14 responden atau $14,14 \%$.

Tabel 11. Hasil regresi linier berganda

\begin{tabular}{crrrr}
\hline \multicolumn{1}{c}{ Variable } & Coefficient & Std. Error & t-Statistic & Prob. \\
\hline C & -135046.0 & 61815.80 & -2.184652 & 0.0314 \\
X1DS & 10653.49 & 15010.20 & 0.709750 & 0.4796 \\
X2 & 5906.467 & 1219.960 & 4.841526 & 0.0000 \\
X3DP & 37538.15 & 18445.36 & 2.035100 & 0.0447 \\
X4DW & 43673.04 & 39705.47 & 1.099925 & 0.2742 \\
X5 & 0.011307 & 0.002589 & 4.366488 & 0.0000 \\
& & & & \\
R-squared & 0.731733 & Mean dependent var & 197373.7 \\
Adjusted R-squared & 0.717310 & S.D. dependent var & 130966.5 \\
S.E. of regression & 69633.02 & Akaike info criterion & 25.19856 \\
Sum squared resid & $4.51 E+11$ & Schwarz criterion & 25.35584 \\
Log likelihood & -1241.329 & Hannan-Quinn criter. & 25.26219 \\
F-statistic & 50.73394 & Durbin-Watson stat & 1.585090 \\
Prob(F-statistic) & 0.000000 & & & \\
\hline Sumber: Data & & & & \\
\hline
\end{tabular}

Sumber : Data diolah, 2019 
Berdarkan hasil olahan data dengan analisis berganda melalui program Eviews 9 di dapat persamaan berikut:

$$
\begin{aligned}
& \mathrm{Y}_{1}=-135046+10653,49 \mathrm{X}_{1 \mathrm{DS}}+5906,467 \mathrm{X} 2_{\mathrm{i}}+37,538,15 \mathrm{X} 3 \mathrm{DP} \mathrm{P}_{\mathrm{i}}+43,673,04 \\
& \mathrm{X} 4 \mathrm{DW} \\
& (-2,1846) \quad(0,7097) \quad(4,8415) \quad(2,0351) \\
& +0,011307 \times 5_{1}+e_{\mathrm{i}} \\
& (4,3664)
\end{aligned}
$$

Variabel jenis kelamin (X1) mempunyai koefisien regresi sebesar 10653,49 memberikan arti bahwa jenis kelamin berpengaruh positif terhadap kesediaan membayar/WTP di TNKS dan besar probabilita 0,4796 siginifikan pada $\alpha=5 \%$. Hal ini menunjukkan bahwa ada perbedaan WTP dari jenis kelamin sebesar Rp. 10.653,49 dengan asumsi variabel lainnya tetap atau konstan (ceteris paribus).

Variabel Usia (X2) mempunyai koefisien regresi sebesar 5906,467 memberikan arti bahwa usia berpengaruh positif terhadap kesediaan membayar/WTP dan besar probabilita 0.0000 siginifikan pada $\alpha=1 \%$. Hal ini menunjukkan bahwa setiap penambahan usia 1 tahun akan terjadi kesediaan membayar/WTP sebesar RP. 5.906,467 dengan asumsi variabel lainnya tetap atau konstan (ceteris paribus).

Variabel Tingkat pendidikan (X3) mempunyai koefisien regresi sebesar 37538.15 memberikan arti bahwa tingkat pendidikan berpengaruh positif terhadap kesediaan membayar/WTP dan besar probabilita 0,0447 siginifikan pada $\alpha=10 \%$. Artinya kesediaan membayar pendidikan perguruan tinggi lebih besar Rp.37.538,15 dari pendidikan SMP ke bawah. Hal ini menunjukkan bahwa semakin tinggi Pendidikan seseorang maka kesediaan membayar/WTP akan terjadi kenaikan dengan asumsi variabel lainnya tetap atau konstan (ceteris paribus).

Variabel Dummy wisatawan (X4) mempunyai koefisien regresi sebesar 43673.04 memberikan arti bahwa asal Wisatawan berpengaruh positif terhadap terhadap kesediaan membayar/WTP dan besar probabilita 0,2742 siginifikan pada $\alpha=10 \%$. Artinya kesediaan membayar/WTP wisatawan yang berkunjung ke TNKS sebesar Rp. 43.6703,04 dengan asumsi variabel lainnya tetap atau konstan (ceteris paribus).

Variabel Pendapatan keluarga (X5) mempunyai koefisien regresi sebesar 0.011307 memberikan arti bahwa pendidikan berpengaruh positif terhadap kesediaan membayar/WTP dan besar probabilita 0,0000 siginifikan pada $\alpha=1 \%$. Hal ini menunjukkan bahwa setiap penambahan 1 pendapatan keluarga akan terjadi kenaikan kesediaan membayar/WTP sebesar Rp. 113,07 dengan asumsi variabel lainnya tetap atau konstan (ceteris paribus).

\section{Pengujian hipotesis \\ Uji F-statistik}

F hitung sebesar 50.73394 dengan probabilitas sebesar $(0,0000)$ atau lebih kecil dari $\alpha=0,05(0,0000<0,05)$ maka $\mathrm{H}_{0}$ ditolak dan $\mathrm{H}_{\mathrm{a}}$ diterima. Artinya secara simultan atau bersama-sama terdapat pengaruh yang signifikan antara jenis kelamin, usia, tingkat Pendidikan, asal wisatawan, dan pendapatan keluarga terhadap kesediaan membayar/WTP di TNKS.

\section{Uji parsial (Uji t)}

Variabel X1DS (Jenis Kelamin) dapat dilihat bahwa nilai t hitung sebesar 0.709750 dengan probabilitas variabel X1DS (Jenis Kelamin) sebesar 0,4796 atau lebih kecil dari nilai $\alpha=0,05(0,0182<0,05)$, maka $\mathrm{H}_{0}$ ditolak dan $\mathrm{H}_{\mathrm{a}}$ diterima. Dari hasil tersebut dapat disimpulkan bahwa secara statistik terdapat perbedaan nyata kesediaan 
membayar/WTP dengan jenis kelamin.

Variabel X2 (Usia) dapat dilihat bahwa nilai t hitung sebesar 4,841526 dengan probabilita variabel usia sebesar 0,0000 atau lebih kecil dari nilai $\alpha=0,01(0,0000<$ 0,01) maka $\mathrm{H}_{0}$ ditolak dan $\mathrm{H}_{\mathrm{a}}$ diterima. Dari hasil tersebut dapat disimpulkan bahwa variabel usia secara individu memiliki pengaruh signifikan terhadap kesediaan membayar/WTP.

Variabel X3 (Pendidikan) dapat dilihat bahwa nilai t hitung sebesar 2,035100 dengan probabilita variabel pendidikan sebesar 0,0447 atau lebih kecil dari nilai $\alpha=$ $0,10(0,0939<0,10)$, maka $\mathrm{H}_{0}$ ditolak dan $\mathrm{H}_{\mathrm{a}}$ diterima. Dari hasil tersebut dapat disimpulkan bahwa variabel pendidikan secara individu memiliki pengaruh signifikan terhadap kesediaan membayar/WTP.

Variabel X4 (Asal Wisatawan) dapat dilihat bahwa nilai t hitung sebesar 1,099925 dengan probabilita variabel asal wisatawan sebesar 0,2742 atau lebih kecil dari nilai $\alpha=0,10(0,0618<0,10)$, maka $\mathrm{H}_{0}$ ditolak dan $\mathrm{H}_{\mathrm{a}}$ diterima. Dari hasil tersebut dapat disimpulkan bahwa variabel asal wisatawan secara individu memiliki pengaruh signifikan terhadap kesediaan membayar/WTP.

Variabel X5 (Pendapatan) dapat dilihat bahwa nilai t hitung sebesar 4,366488 dengan probabilita variabel pendapatan sebesar 0.0000 atau lebih kecil dari nilai $\alpha=$ $0,01(0.0000<0,01)$, maka $\mathrm{H}_{0}$ ditolak dan $\mathrm{H}_{\mathrm{a}}$ diterima. Dari hasil tersebut dapat disimpulkan bahwa variabel jumlah penumpang secara individu memiliki pengaruh signifikan terhadap kesediaan membayar/WTP.

\section{Koefisien determinasi $\left(\mathbf{R}^{2}\right)$}

Pengaruh variabel bebas (jenis kelamin, usia, Pendidikan, asal wisatawan, dan pendapatan) terhadap variabel terikat (kesediaan membayar/Willingness To Pay) ditunjukkan oleh besar koefisien determinasi $\mathrm{R}^{2}$. Diperoleh angka R-squared sebesar 0.731733 atau $73,17 \%$ menunjukkan bahwa $73,17 \%$ kesediaan membayar/WTP disebabkan oleh jenis kelamin, usia, Pendidikan, asal wisatawan, dan pendapatan. Sedangkan sisanya sebesar $26,83 \%$ disebabkan oleh variabel lain yang tidak dimasukkan dalam model penelitian ini.

\section{Uji asumsi klasik}

\section{Uji multikolinearitas}

Untuk mengetahui adanya korelasi linier antar variabel bebas dalam model empiris. Multikolinearitas dapat dilihat juga dari tolerance and variance inflation factors (VIF).

Tabel 12. Hasil Variance Inflation Factor (VIF)

\begin{tabular}{|c|c|c|c|}
\hline Variable & $\begin{array}{c}\text { Coefficient } \\
\text { Variance }\end{array}$ & $\begin{array}{c}\text { Uncentered } \\
\text { VIF }\end{array}$ & $\begin{array}{c}\text { Centered } \\
\text { VIF }\end{array}$ \\
\hline $\mathrm{C}$ & $3.82 \mathrm{E}+09$ & 78.01960 & NA \\
\hline X1DS & $2.25 \mathrm{E}+08$ & 2.834473 & 1.087980 \\
\hline X2 & 1488302. & 29.16284 & 1.961180 \\
\hline $\mathrm{X} 3 \mathrm{DP}$ & $3.40 \mathrm{E}+08$ & 4.490800 & 1.587657 \\
\hline X4DW & $1.58 \mathrm{E}+09$ & 22.10951 & 6.923181 \\
\hline X5 & 6.71E-06 & 16.56717 & 6.928104 \\
\hline
\end{tabular}

Sumber : Data diolah, 2019

Hasil tersebut terlihat bahwa VIF variabel X1DS (Dummy Jenis Kelamin), X2 (Usia), X3DP (Dummy Pendidikan), X4DW (Dummy Asal Wisatawan), dan X5 
(Pendapatan) terhadap kesediaan membayar/WTP kurang dari 10 maka dapat dinyatakan tidak terjadi gejala multikolinearitas.

\section{Uji heterokedastisitas}

Untuk menguji masalah heterokedastisitas pada model ini maka digunakan pengujian Breusch-Pagan-Godfrey. Jika terjadi heterokedastisitas maka penaksir OLS tetap tak bias atau konsisten, tetapi penaksir tadi tidak lagi efisien baik dalam sampel kecil maupun besar. Berikut ini model heterokedastisitas dapat dilihat pada tabel 10:

Tabel 13. Hasil regresi heterokedastisitas

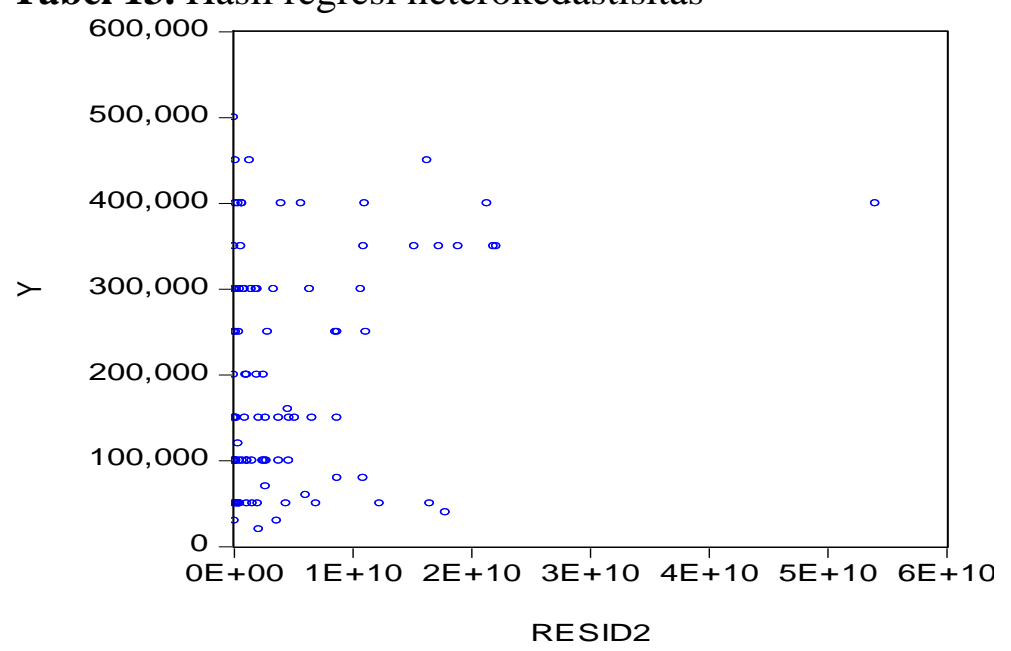

Sumber : Output Eviews data diolah, 2019

\section{Uji autokorelasi}

Autokorelasi adalah yang terjadi dalam satu variabel. Korelasi ini terjadi antar waktu atau individu. Umumnya kasus autokorelasi banyak terjadi pada data time series, artinya kondisi sekarang dipengaruhi waktu yang lalu. Berikut hasil dan penjelasannya:

Tabel 14. Hasil regresi autokorelasi

\begin{tabular}{llll}
\hline F-statistic & 1.349358 & Prob. F(4,89) & 0.2580 \\
Obs*R-squared & 5.660597 & Prob. Chi-Square(4) & 0.2260
\end{tabular}

Sumber : Data diolah, 2019

\section{Uji normalitas}

Uji yang dilakukan untuk mengevaluasi apakah nilai variabel pengganggu dari model yang dibentuk sudah normal atau tidak. Konsep pengujian uji normalitas menggunakan pendekatan Jorque-Berra test. 


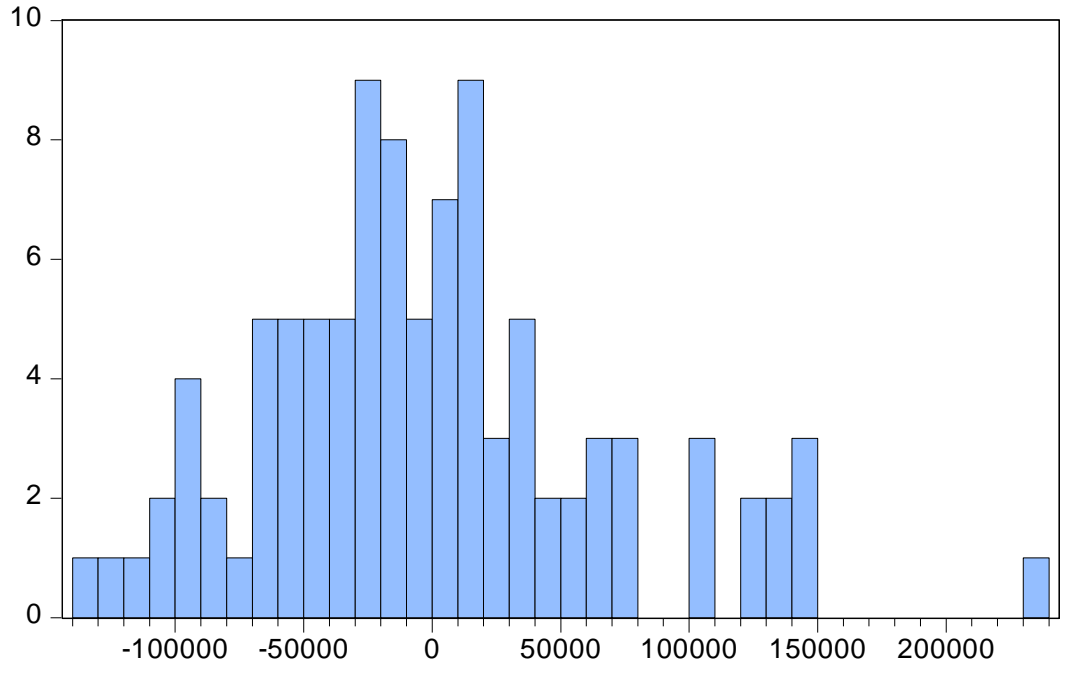

Gambar.1. Uji normalitas
Series: Residuals

Sample 199

Observations 99

Mean

$5.13 \mathrm{e}-11$

Median

$-7810.033$

Maximum

232426.1

Minimum $\quad-133480.4$

Std. Dev. $\quad 67833.41$

Skewness $\quad 0.707977$

Kurtosis

3.703882

Jarque-Bera $\quad 10.31404$

Probability

Hasil grafik uji normalitas menunjukan bahwa nilai probabilita J-B hitung 0,005759 lebih kecil dari nilai probabilitas $\alpha(0,05)$ dalam pendekatan Jarque-Berra test, maka model ini tidak lolos dari ketidaknormalan atau data berdistribusi normal.

\section{Pengaruh Jenis Kelamin Terhadap Willingness To Pay}

Berdasarkan wawancara yang dilakukan di TNKS menunjukkan bahwa wanita dan pria memiliki kemauan membayar yang sama untuk menilai keindahan wisata alam di TNKS, sehingga dapat disimpulkan bahwa variabel jenis kelamin tidak berpenagruh signifikan terhadap kesediaan membayar di TNKS.

\section{Pengaruh Usia terhadap Terhadap Willingness To Pay}

Variabel usia berpengaruh positif dan signifikan terhadap Willingness To Pay. Berdasarkan hasil penelitian menunjukkan bahwa umur seseorang dapat berpengaruh terhadap kemauan membayar (willingness to pay). Umur seorang individu dapat menggambarkan fakta bahwa tiap individu memiliki kecenderungan untuk membayar yang berbeda-beda (Andersen (1974) dalam Notoatmodjo (2005)).

\section{Pengaruh Tingkat Pendidikan Terhadap Willingness To Pay}

Tingkat Pendidikan berpengaruh positif atau signifikan terhadap Willingness To Pay. Dapat dilihat dari hasil penelitian bahwa semakin tinggi pendidikan seseorang maka kemauan untuk membayar wisata alam TNKS semakin besar karena seseorang yang memiliki pendidikan yang tinggi pemikiran wawasan serta pandangan, pemahaman dan penilaian akan pentingnya lingkungan yang lebih baik untuk mendukung melestarikan wisata alam di TNKS.

\section{Pengaruh Asal Wisatawan Terhadap Willingness To Pay}

Dari hasil wawancara yang dilakukan di TNKS menunjukkan bahwa wisatawan mancanegara memiliki kemauan membayar yang tinggi dibandingkan wisatawan nusantara namun dikarenakan jumlah wisatawan mancanegara yang cenderung lebih sedikit dibandingkan dengan wisatawan nusantara.

\section{Pengaruh Pendapatan Keluarga Terhadap Willingness To Pay}

Pendapatan keluarga berpengaruh positif atau signifikan terhadap Willingness To Pay. Hasil ini sesuai dengan penelitian yang dilakukan oleh (Amanda, 2009) yang menyimpulkan juga bahwa pendapatan berpengaruh positif terhadap nilai WTP, artinya setiap kenaikan jumlah pendapatan pengunjung akan meningkatkan nilai WTP. Pendapatan pengunjung mempengaruhi besarnya nilai WTP karena pendapatan yang 
tinggi akan memiliki dana lebih untuk mengeluarkan biaya lainnya, dalam hal ini yaitu untuk mendukung pengembangan ekowisata berkelanjutan.

Dari hasil penelitian yang dilakukan di TNKS menunjukkan bahwa seseorang yang sudah bekerja dan sudah berpendapatan memiliki kemauan untuk membayar wisata alam TNKS lebih besar dibandingkan dengan seseorang yang belum bekerja dan belum berpendapatan.

\section{KESIMPULAN DAN SARAN}

\section{Kesimpulan}

Berdasarkan hasil dari uraian pada hasil penelitian, maka dapat diambil kesimpulan bahwa potensi Sumber Daya Wisata Alam TNKS di Kabupaten Kerinci ditunjukkan oleh kekayaan flora dan fauna dengan keanekaragamannya yang sangat tinggi khususnya dalam kawasan Taman Nasional Kerinci Seblat (TNKS).

Perkembangan kunjungan Wisata Alam di TNKS baik itu Wisatawan Mancanegara maupun Wisatawan Nusantara tahun 2000-2018 mengalami fluktuasi disetiap tahunnya, Kenaikan secara pesat hanya terjadi pada tahun 2016 yakni mencapai 7465 orang. Namun pada tahun 2017 terjadi penurunan sekitar 61\% kemudian pada tahun 2018 terjadi kenaikan kembali sebesar 125\%. Berbeda dengan wisatawan nusantara yang mengalami naik turunnya jumlah kunjungan dari tahun ke tahun, pada tahun 2000 jumlah wisnus lebih sedikit dibandingkan dengan tahun yang lainnya yaitu hanya sebesar 88807 orang dan pada tahun 2018 mengalami kenaikan yang sangat pesat yakni sebesar 349326 orang.

Nilai ekonomi wisata alam dikawasan TNKS di Kabupaten Kerinci untuk tetap dapat menikmati jasa pariwisata alam dimaksud sebesar Rp.488.075.000,- dengan ratarata nilai kesediaan membayar/WTP sebesar Rp. 252.500,- per orang.

Faktor-faktor yang mempengaruhi nilai ekonomi wisatawa alam dikawasan TNKS di Kabupaten Kerinci berdasarkan hasil regresi linier berganda diperoleh hasil secara simultan atau bersama-sama, jenis kelamin, usia, tingkat Pendidikan, asal wisatawan, dan pendapatan keluarga berpengaruh positif terhadap Willingness to pay/ kesediaan membayar.

\section{Saran}

Berdasarkan hasil penelitian yang telah diuraikan dan kesimpulan yang diperoleh penulis mengajukan beberapa saran untuk menjaga Sumber Daya Alam yang ada di TNKS termasuk flora dan fauna yang sudah mulai langka, dan menjaga kebersihan agar Sumber Daya Alam tidak rusak dan bisa meningkatkan minat pengunjung untuk berwisata ke TNKS.

Untuk meningkatkan perkembangan wisata alam di TNKS termasuk kunjungan Wisatawan perlu dilakukan kegiatan promosi jasa wisata secara intensif terutama menyangkut hal yang unik dan spesifik flora dan fauna TNKS atau jasa wisata alam lainnya.

Nilai kesediaan membayar atau WTP seseorang didapatkan dengan cara menikmati wisata alam yang ada di TNKS, maka dari itu wisata alam di TNKS harus lebih diperhatikan dalam segi kebersihan dan keindahan alamnya agar pengunjung bisa menikmati keindahan alam yang ada dan memiliki nilai ekonomi yang tinggi.

Untuk meningkatkan kesediaan membayar atau WTP, Sumber Daya Alam harus lebih diperhatikan dan menjaga kebersihan dikawasan TNKS karena masih banyak sekali penampakan sampah disepanjang jalan agar semua pengunjung yang datang untuk berwisata atau untuk melakukan penelitian di TNKS dapat merasa nyaman dan tertarik untuk terus berkunjunga ke TNKS. 


\section{DAFTAR PUSTAKA}

Bashir, A. (2014). Pengaruh Sektor Pariwisata Terhadap Pertumbuhan Ekonomi. http://asyharnotes.blogspot.com diakses pada 30 November 2014.

Case, Karl E., dan Ray C. Fair. (2007). Prinsip - Prinsip Ekonomi. Jakarta :Penerbit Erlangga.

Dinas Kebudayaan dan Pariwisata Provinsi Jawa Timur. (2014). Jumlah Kunjungan Wisatawan di Jawa Timur. http://disbudpar.jatimprov.go.id diakses pada 22 Desember 2014.

Djijono. (2002). Valuasi Ekonomi Menggunakan Metode Travel Cost Taman Wisata Hutan di Taman Wan Abdul Rachman, propinsi Lampung. Makalah Pengantar Falsafah Sains (PPS702) Institut Pertanian Bogor.

Igunawati, Diana. 2010. Analisis Permintaan Objek Wisata Tirta Waduk Cacaban, Kabupaten Tegal. Skripsi. Fakultas Ekonomi Universitas Diponegoro Semarang.

Nugroho, P Setyo. (2010). Valuasi Ekonomi Wisata Pantai Glagah Dengan Pendekatan Biaya Perjalanan (Travel Cost) di Desa Glagah Kecamatan Temon Kabupaten Kulon Progo. Skripsi. Fakultas Ekonomi Universitas Sebelas Maret Surakarta.

Safri, Muhammad. (2003). Dampak Pariwisata Alam Taman Nasional Kerinci Seblat Terhadap Ekonomi Masyarakat Sekitar dan Wilayah Kabupaten Kerinci Provinsi Jambi. Riset. IPB. Bogor.

Samdin, Z. (2008). Willingness to Pay in Taman Negara: A Contingent Valuation Method. International Journal of Economics and Management, Universiti Putra Malaysia, 43400, Serdang, Selangor, Malaysia.

Subadra, I Nengah. (2007). Bali Tourism Watch: Peran Pemerintah dalam Pembangunan Pariwisata. http://subadra.wordpress.com diakses pada 21 Desember 2014.

Susilowati. (2002). Sumber Daya Alam dan Lingkungan dengan Pendekatan Contingent Valuation Method. Skripsi. Fakultas Ekonomi Universitas Lampung. 